\title{
Causality within the Euro Area? : Trade Surplus in the North versus Public Debt in the South
}

\author{
George K. Zestos \\ Christopher Newport University, Newport News, United States \\ Travis K. Taylor \\ Christopher Newport University, Newport News, United States \\ Ryan D. Patnode \\ Christopher Newport University, Newport News, United States
}

\begin{abstract}
The United States subprime mortgage crisis began to spread to Europe in 2008. The worst affected were periphery countries that experienced drastic declines in international competitiveness and thus accumulated large public debts. High public debt drove countries such as Greece, Ireland, Portugal, Cyprus, and Spain to the verge of economic collapse. This study examines whether trade imbalances led to high public indebtedness in the periphery euro area countries. To investigate the impact of northern euro area countries' trade surpluses on southern euro area countries' public debt, we estimated bivariate and trivariate Vector Error Correction Models. We then employed these estimated models to test for Granger causality between trade imbalances and public debt.

\footnotetext{
* Corresponding Author: George K. Zestos; Christopher Newport University, Department of Economics, 1 Avenue of the Arts Luter Hall Room 226, Newport News VA, 23606, United States, Tel: 757-594-7067, Fax: 757-594-8953, E-mail: gzestos@cnu.edu

Co-author: Travis K. Taylor; Christopher Newport University, Department of Economics, 1 Avenue of the Arts Luter Hall Room 222, Newport News VA, 23606, United States, Tel: 757-594-7148, Fax: 757-594-8953, E-mail: ttaylor@cnu.edu

Co-author: Ryan D. Patnode; Christopher Newport University, 1000 University Place Box \#3827, Newport News VA, 23606, United States, Tel: 703-987-0601, Fax: 757-594-8953, E-mail: ryan.patnode.14@cnu.edu

Acknowledgements: We thank the European Union for funding support via Dr. George Zestos' Jean Monnet Chair of European Integration. We are grateful to Christopher Newport University for co-sponsoring the research. We also thank Dr. Roark Mulligan for editing and constructive criticism of the paper. We thank Michael Williamson for excellent research assistance. Similarly, we express gratitude to the participants of the International Academy of Business and Public Administration Disciplines (IABPAD) conferences held in Madrid, Spain, July 23 26, 2014 and Orlando, Florida, January 3 5, 2016 for feedback on earlier drafts.
} 
We found that trade surpluses in the northern euro area countries caused an increase in public debt in the periphery countries. However, only limited evidence for reverse causality was found.

JEL Classification: C12, F14, F15, F45

Keywords: European Sovereign Debt Crisis, Trade Imbalances, Cointegration, Vector Error Correction Models, Granger Causality Tests.

\section{Introduction}

After devastating the United States (US) economy in 2007 2008, the subprime mortgage crisis affected Europe through financial integration and contagion. The countries that were most exposed to the crisis were the European Union (EU) members whose financial institutions had heavily invested in US and in domestic mortgagerelated synthetic securities (financial derivatives). Because many of those securities were backed by non-performing mortgages, the securities were of low quality and became known as toxic. Another group of European countries afflicted by the crisis experienced excessive public deficits and debts. The latter were triggered by deteriorating international competitiveness, as indicated by their large Current Account (CA) deficits from 2008 to 2009. ${ }^{1}$

Interest rates on government bonds of over-indebted countries began rising rapidly because investors demanded to be compensated with risk premia for exposure to the public debt of these countries. Because the over-indebted countries were members of the Euro Area (EA), the International Monetary Fund (IMF) and the EU jointly bailed out these financially distressed countries.

This study examines whether trade imbalances in the EA contributed to acute indebtedness in the southern EA countries and Ireland (periphery) and resulted in macroeconomic instability. To investigate whether there was a causal relationship between northern EA countries' trade surpluses and southern EA countries' public debtto-Gross Domestic Product (GDP) ratio, we estimate three Vector Error Correction

\footnotetext{
${ }^{1}$ CA deficits began increasing after the launch of the Euro in 1999. Since the trade balance is the most important part of the CA, we use these terms interchangeably in this study.
} 
Models (VECMs). Based on these models, we perform Granger causality tests and find evidence of asymmetry: Northern EA trade surpluses Granger cause southern EA indebtedness, but evidence of reverse causality is only weakly supported by the trivariate VECM. This study makes a significant contribution to the literature as it is the first to employ these variables with VECMs. Furthermore, the results are important for policy purposes as large trade imbalances can have detrimental effects on trading partners that accumulate large trade deficits. Thus, excessive increases in trade imbalances must be prevented in the integrated international economy.

The remainder of the study is organized as follows. Section II addresses the issues of public debt and trade balances in the EA, as well as the factors that influenced them during the euro crisis. Section II also provides historical context to the structure of the Economic and Monetary Union (EMU). Section III outlines the policies proposed by the EU and IMF to assist the indebted countries and the eventual rebalancing of trade and CAs within the EA and beyond. Section IV reviews the literature. Section V estimates two bivariate and one trivariate VECM. These models are constructed to study the hypothesized endogenous, long-term equilibrium relation among northern EA surpluses on CA, periphery EA countries' public debt, and GDP growth of periphery EA countries. Section VI offers concluding remarks.

\section{Trend Analysis}

\section{A. Euro area public debt}

The accumulation of high public debt-to-GDP ratios in several EA countries constitutes the center of the euro crisis. The public debt crisis asymmetrically affected the EA countries. Figure 1 depicts the public debt-to-GDP ratios of five selected northern EA (core) countries, Belgium, Germany, France, Netherlands, and Austria, for the 1999 2014 period. Figure 2 shows the public debt-to-GDP ratios of five selected southern EA (periphery) countries, Greece, Spain, Italy, Portugal, and Ireland, over the same period. ${ }^{2}$ These figures clearly indicate that the public debt-to-GDP ratios

\footnotetext{
${ }^{2}$ Ireland is, of course, not a southern EA country, but is included with the southern EA group because its economy was affected just as the southern EA countries were.
} 
began increasing at the onset of the crisis in 2007 for all 10 EA countries. The main difference between the two groups is that the increases of the public debt-to-GDP ratios in the northern EA group were relatively modest as only Belgium's debt-to-GDP ratio exceeded 100 percent. However, the public debt-to-GDP ratios in the southern EA countries increased substantially; for example, four countries' public debt-to-GDP ratios surpassed 100 percent. $^{3}$ Notably, each of the 10 EA countries exceeded the official Maastricht criterion of a public debt-to-GDP ratio of 60 percent. ${ }^{4}$

\section{Figure 1. Northern euro area public debt}

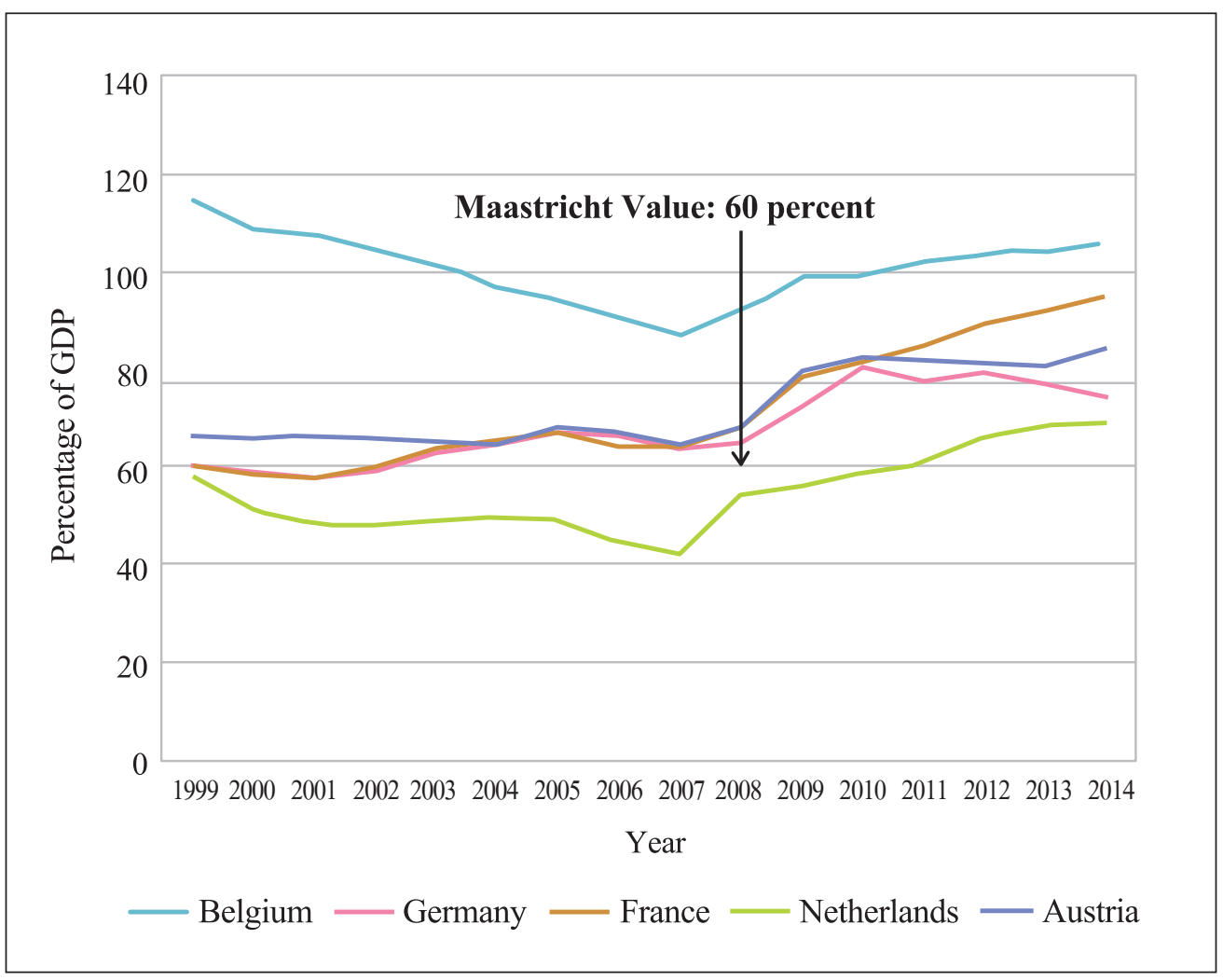

(Source) Eurostat

\footnotetext{
${ }^{3}$ Among the periphery EA countries, Spain was the only country that kept its public debt-to-GDP ratio below $100 \%$.

${ }^{4}$ Greece, Italy, and Belgium joined the EMU although they exceeded the maximum public debt-to-GDP convergence criterion. The EU country leaders waived the Maastricht public debt criterion to allow these three countries to join the EMU. European monetary integration was a strong political commitment of the EU country leaders who established the EMU.
} 
Figure 2. Southern euro area public debt

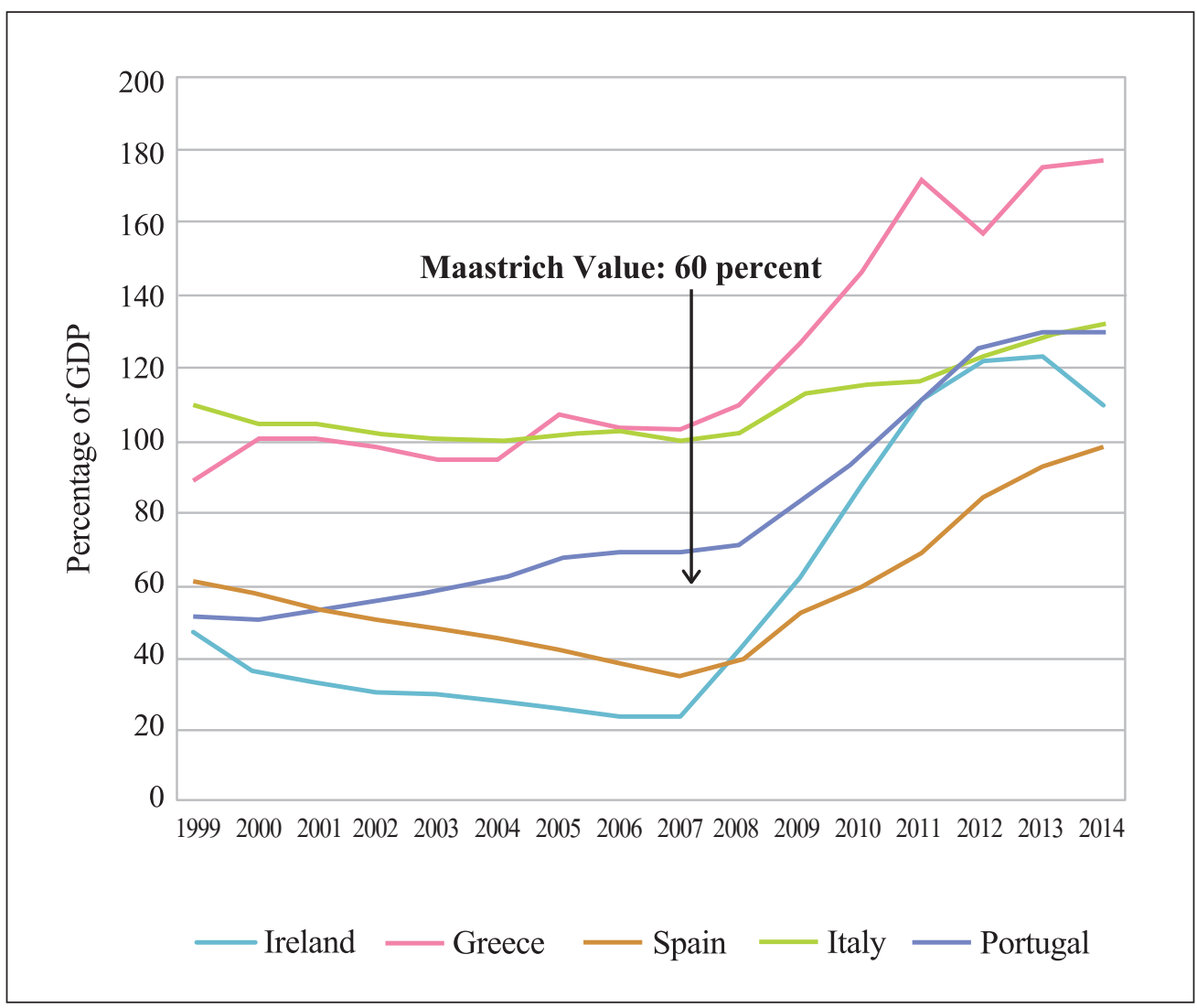

(Source) Eurostat

With the onset of the crisis in Europe, a general consensus emerged among EU leaders that the crisis was caused by excessive borrowing and spending by the southern EA members and Ireland. The solution to the crisis was, therefore, sought in fiscal austerity and supply-side structural reforms to help over-indebted countries regain their international competitiveness and improve widening CA deficits. Such policies, it was believed, would help countries reduce their public debt and thus recover from the recession. ${ }^{5}$ Countries that officially agreed to adopt structural reforms, such as privatization programs, wage and pension cuts in both the private and public sectors, and fiscal discipline, qualified for the joint IMF-EU-European Central Bank (ECB) bailout programs. Germany argued that countries receiving bailouts must also include haircuts

${ }^{5}$ See Alessandrini et al. (2014). 
(losses) to their privately held outstanding public debt; this meant that investors of public debt would have to accept a reduction in the value of their bond holdings. ${ }^{6}$

The austerity programs worsened economic conditions in the EA periphery, particularly in Greece and Spain, which experienced prolonged unemployment rates of close to $25 \%$. Austerity programs were challenged by workers in Southern Europe and other EU countries. During the joint October 2012 IMF/World Bank meetings in Tokyo, IMF Chief Christine Lagarde expressed concern that austerity programs and fiscal consolidations alone would not be sufficient to end the recessions in the overindebted countries. Instead, she said, growth programs should be adopted to complement the austerity measures. Growth programs began to gain support among the EA members, despite vehement opposition by German Finance Minister Wolfgang Schäuble. As of October 2016, however, growth policies have yet to be launched and the euro crisis continues.

\section{B. Causes of the euro area trade imbalances}

The causes of the EA trade imbalances are numerous and still widely debated. In section 1, we discuss the EMU structure as both a cause of the euro crisis and a major factor in explaining why it remains unresolved. In Section 2, we present historical data on trade asymmetries between the northern and southern EA countries.

\section{An incomplete structure}

What caused the asymmetric impact on the EA countries that led some countries to generate unsustainable debts while others went almost unscathed? Was the intrinsic structure of the EMU responsible for preventing EA countries from resolving the crisis? Most economists agree that the EMU was launched as an incomplete program. ${ }^{7}$ The EMU created a common monetary policy regime with one currency and one interest rate for all countries. It was known that this policy would not prevent a major economic calamity unless member countries experienced synchronized business cycles. Thus, the formation of the EMU signaled an end to autonomous macroeconomic national policy

\footnotetext{
${ }^{6}$ These haircuts are also known as Private Sector Involvement (PSI) programs. It is now understood that the Greek PSI not only worsened conditions in Greece, but also caused contagion to other periphery countries.

${ }^{7}$ See Stockhammer (2011), Lane (2012), Zestos (2006), Zestos (2016) among many other studies.
} 
making as monetary and exchange rate policies are conducted by the ECB. The crisis clearly showed that a one-size-fits-all monetary policy was incapable of working in the presence of asymmetric shocks to the EA.

The conventional policy prescription of currency devaluation to combat CA deficits and economic contraction is no longer available to EA countries. Within the EMU, the only way member countries can fight recessions is by inducing growth through internal devaluation; however, this path is often a frustratingly slow process owing to sticky prices and downward wage rigidity. According to its charter, the ECB has only one major mandate - price stability. ${ }^{8}$ Notably, the ECB was unable to perform all the critical functions that modern central banks can to protect EMU member countries from economic calamities. For example, the ECB could not serve as a lender of last resort by buying the EMU countries' national bonds when such countries were financially distressed.

Furthermore, the EU and EA member countries do not share a common fiscal policy to assist countries in the case of natural catastrophes or abnormal economic conditions. Since EA countries have surrendered most of their fiscal policy tools to comply with the Stability and Growth Pact (SGP), their ability to cope with recessions is severely impaired. ${ }^{10}$ Considering all the shortcomings of the EMU, it should not come as a surprise that the European financial crisis has proved to be both prolonged and severe.

\section{Trade asymmetries}

By observing the CA balances of the northern and southern EA countries in Figure 3 and Figure 4 below, it is evident that since the introduction of the euro in 1999, the two EA groups' performance has diverged substantially. Most core EA countries consistently generated trade surpluses, while the periphery EA countries experienced CA deficits. ${ }^{11}$ Owing to reduced national income at the onset of the crisis, southern EA countries' CA deficits began shrinking. ${ }^{12}$ During the crisis, the Netherlands' and Germany's CA

\footnotetext{
${ }^{8}$ This is unlike its counterpart in the US, The Fed, which has a dual mandate of both price stability and full employment.

${ }^{9}$ The EU budget is about one percent of the EU's GDP. Most economists agree this is too small to have any significant countercyclical effects in assisting countries at risk. See Alessandrini et al. (2014) and Zestos (2006).

${ }^{10}$ According to the SGP, EMU members must keep public deficits and debts below $3 \%$ and $60 \%$ of their GDPs, respectively, after the establishment of the EMU. The SGP was violated by most countries, including Germany, which initiated and insistently pushed for its approval.

${ }^{11}$ France is an exception among the northern EA group because it generated small CA deficits since 2006, whereas Belgium, for the entire period, generated an almost always balanced CA.

${ }^{12}$ For the periphery EA group, nonetheless, Ireland constitutes an exception because it generated trade surpluses from 2010 , before all other periphery countries.
} 
surpluses increased and, in April 2015, remained above 9.2\% and 7.5\% of their GDPs, respectively.

Figure 3. Current accounts of northern euro area countries

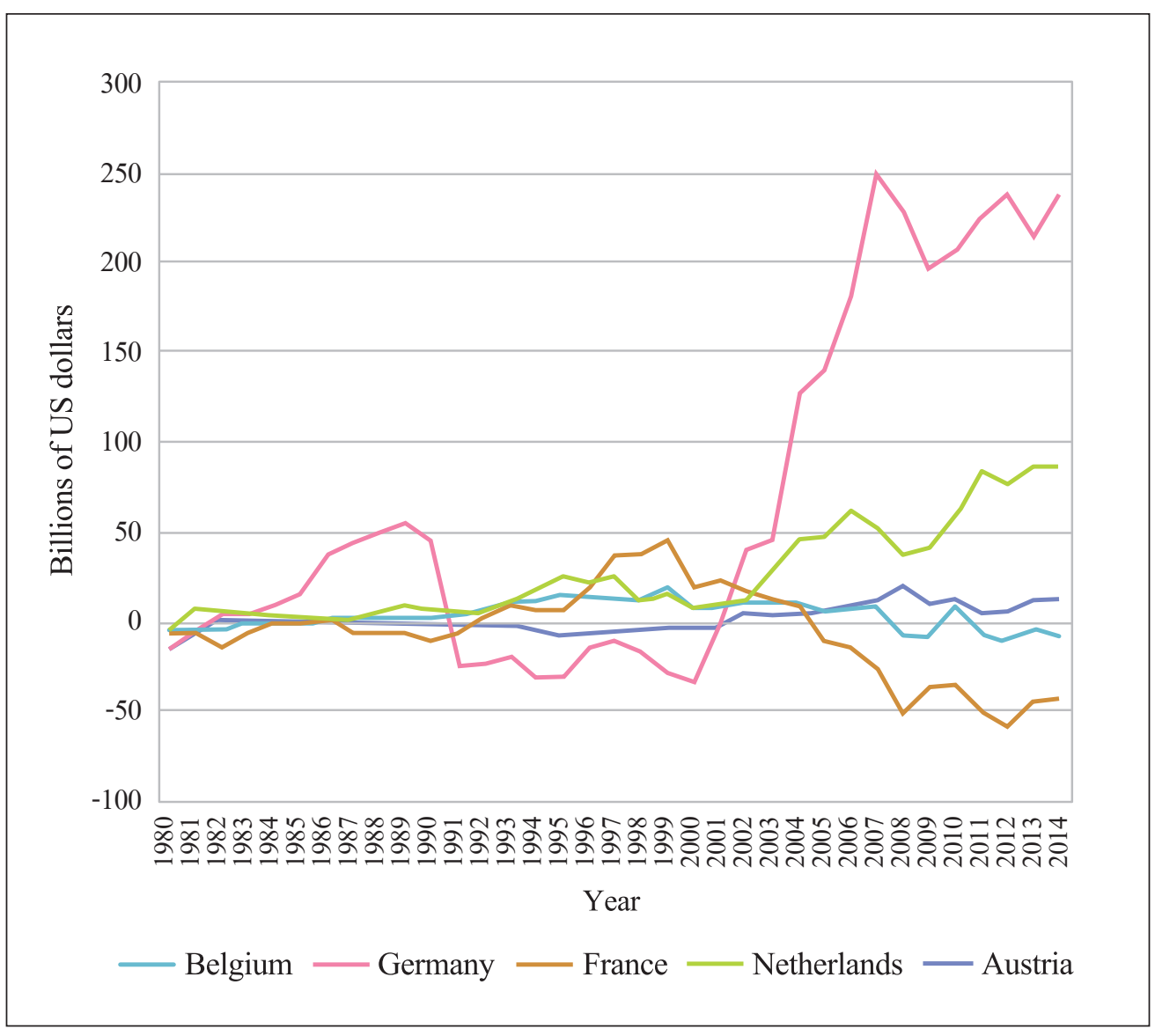

(Source) Eurostat 


\section{Figure 4. Current accounts of southern euro area countries}

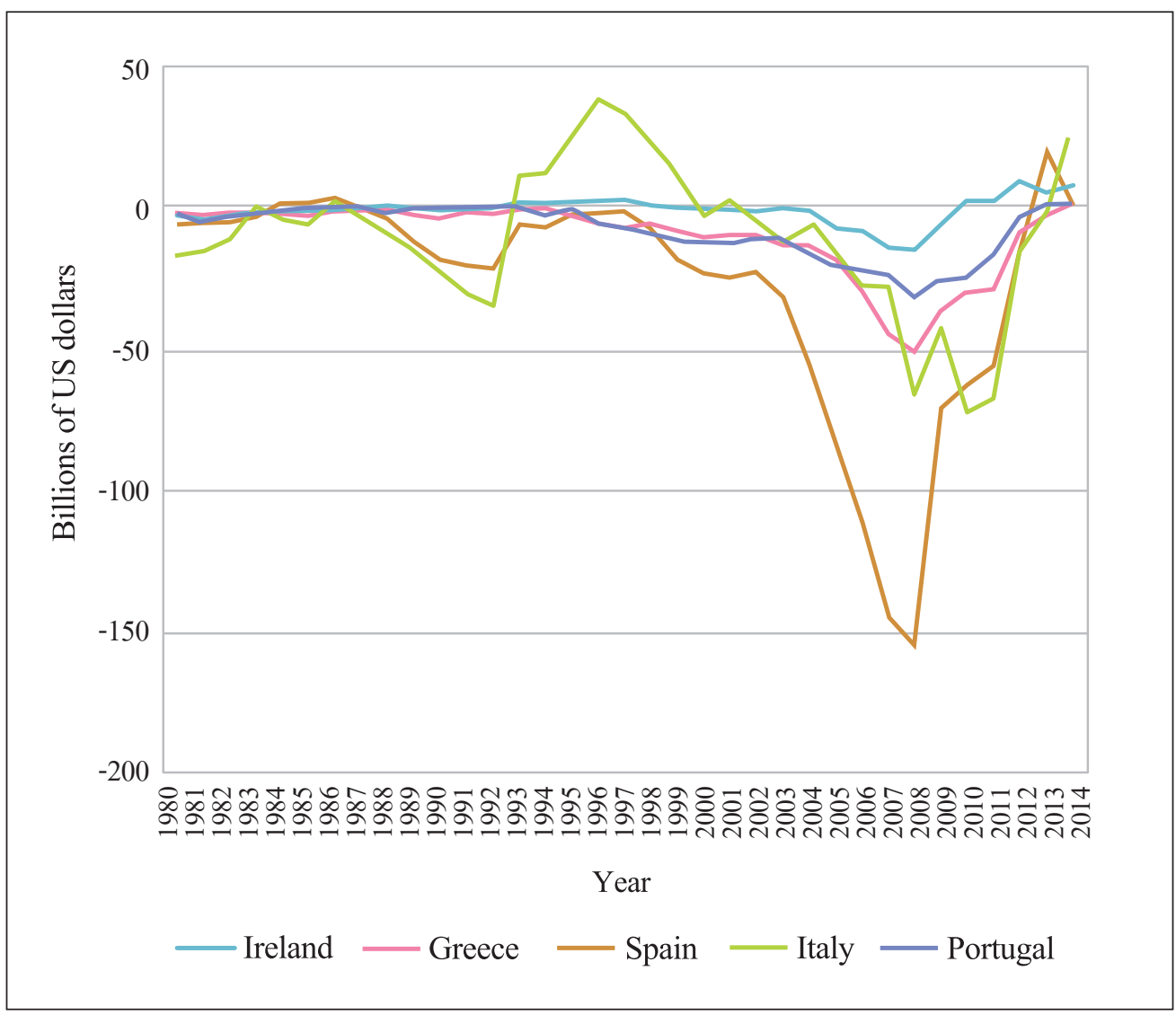

(Source) Eurostat

Setting aside the imperfections of the EMU, there are many policies and institutional arrangements in the EU that contributed to economic development and real convergence among all EU countries. Such convergence began in the 1950s and continued through the first 10 years of the EMU. ${ }^{13}$ These benefits were the result of the formation of the Single European Market (SEM), low inflation experienced by all member countries, and the launch of cohesion policies. ${ }^{14}$ The financial crisis stalled this process, however, and the EU has since been experiencing disintegration.

\footnotetext{
${ }^{13}$ See Zestos and Yin (2009) and Yin, Zestos, and Michelis (2003), among other empirical studies, which found evidence of real convergence in terms of real per capita GDP in the EU countries. Convergence, however, ended at the onset of the crisis.

${ }^{14}$ Cohesion policies refer to regional, social, and agricultural policies designed to reduce income inequality among and within member countries.
} 


\section{Policy Reforms and Rebalancing}

Trade imbalances may have been allowed to grow because EU country leaders were not aware of their potential severity and downside risk. Since 1945, however, the IMF has been assisting countries with distorted balance of payments accounts. In such instances, the IMF typically offers structural adjustment loans to the crisis-affected countries. These loans are contingent upon the recipient country's adoption of strict austerity programs. In 2009, German Chancellor Angela Merkel invited the IMF to contribute to the design and administration of the bailout programs. Such a decision was unsound and unusual on two grounds. First, the IMF, as a general rule, assists less developed countries with balance of payments problems and excessive public debts. The EU consists mostly of developed countries that could have supported each other, particularly if they had taken the initiative before interest rates began rising rapidly. Second, the invitation of the IMF would have been unnecessary if the EU countries had pursued harmonious development and balanced growth policies according to Article 2 of the Treaty of Rome. However, the countries failed to do so, thus the spirit of the article has been grossly ignored at a critical time for the community (EU).

One can claim that fiscally profligate countries should be denied any assistance. This judgment, however, would pertain only to Greece and not to other periphery countries. ${ }^{15}$ Corrupt Greek politicians practiced clientelism for many years, exchanging favors (jobs) for votes. Such behavior must have played a role in increasing the public debt to unsustainable levels. In addition, the same politicians accepted bribes from domestic and foreign firms, thus acting against the interests of their own country.

In 2014, Greece generated a small, positive annual rate of growth but also lost more than $25 \%$ of its pre-crisis national income. It saw an increase in homelessness, poverty, violence, and the popularity of the Neo-Nazi party, Golden Dawn. The main reason for the prolonged recessions of Greece, Ireland, Portugal, and, especially Cyprus was that the terms of the bailouts were initially unfavorable; they included high interest rates above those the EU had to pay in the market to obtain funds. Such unfavorable bailout terms were designed to dissuade other countries from seeking bailouts. In this way, the

\footnotetext{
${ }^{15}$ The origins of the crises in Ireland, Spain, and Portugal are distinct from those in Greece. Rising risk premia and jittery markets, as a result of the contagion effect from Greece, forced these governments to intervene and assist their over-indebted private sectors. Ireland, for example, quickly transformed a significant portion of its private debt into public debt when it guaranteed bank deposits equal to 2.5 times its GDP.
} 
EU leaders attempted to address the moral hazard problem.

An intra-EA rebalancing would have required a decrease in real wages in CA deficit countries and an increase in real wages in surplus countries. More generally, rebalancing called for an internal devaluation for the periphery countries and an internal revaluation for core EA countries. There is, however, evidence that redirection of trade within the EA countries is occurring. For example, Germany in 2011 generated $70 \%$ of its trade surplus with non-EU countries. Approximately $23 \%$ of its trade surplus is with the EU but non-EA countries and only $7 \%$ is with EA countries. This implies disintegration within the EA. ${ }^{16}$ According to these trade statistics, combined with the information in Figure 3 and Figure 4, the intra-EA rebalancing problem can be said to no longer exist.

It is evident from Figure 3 and Figure 4 that the CA deficits of the southern EA countries and Ireland have been drastically reduced since the financial crisis affected Europe. While the southern EA deficits were transformed into surpluses, the balances of the northern EA countries remained positive and excessive. Germany's CA surpluses were so large that the EU Commission began an investigation into whether such surpluses could be destabilizing the EA economy. Figure 5 clearly indicates that Germany drastically reduced its trade with the EU while increasing it with countries outside the EU. ${ }^{17}$

\footnotetext{
${ }^{16}$ See Darvas (2012). Such redirection of trade is not opposed by economists if it is a result of the principle of comparative advantage. If, however, it is the result of German strategic trade policy, this may have implications for the future of the EMU and the EU.

${ }^{17}$ The graph in Figure 3 was first printed in the textbook by Zestos (2016), Global Financial Crisis: From the US Subprime Mortgages to the European Sovereign Debt, Routledge UK.
} 
Figure 5. German trade $\operatorname{data}^{18}$

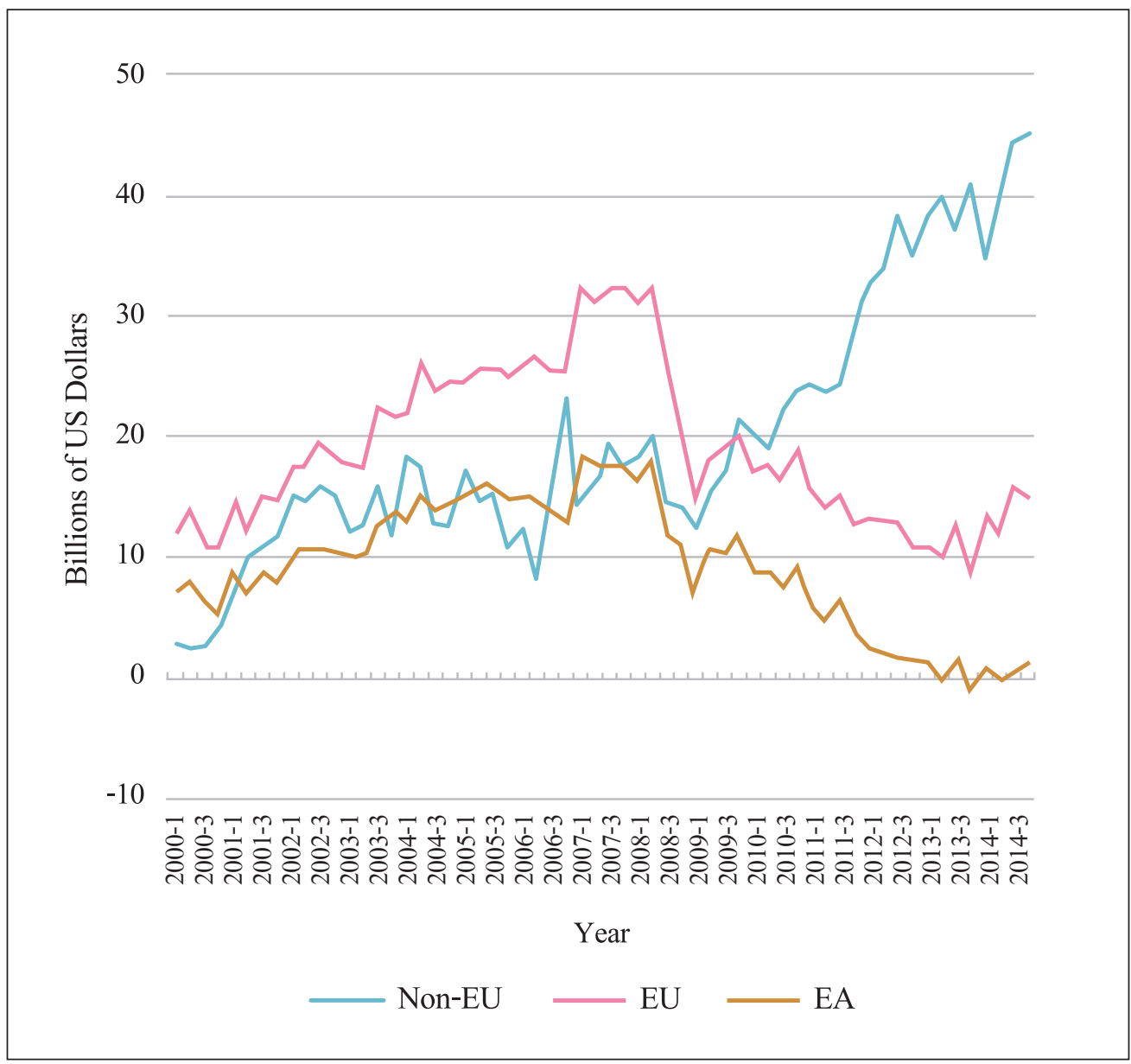

(Source) Eurostat

\section{Literature Review}

Trade imbalances first began receiving attention in the early 1980s, when the US was generating massive CA deficits. Economists and other analysts offered numerous

\footnotetext{
${ }^{18}$ We thank Zsolt Darvas of the Bruegel Institute in Brussels for providing the data and source for Figure 5.
} 
explanations for these large US imbalances on the CA. Many of these explanations focused on the international competitiveness of the country, which is typically affected by labor productivity, unit labor costs, and misaligned real exchange rates. Another approach to trade imbalances, however, is to examine possible macroeconomic imbalances of the domestic economy. This is typically shown by the macroeconomic identity where trade deficits $(\mathrm{M}-\mathrm{X})$ of the US are equal to the sum of $(\mathrm{G}-\mathrm{T})$ and $(\mathrm{I}-\mathrm{S}){ }^{19}$

The US maintained public deficits for a long period during which many economists were convinced that US saving was very low in relation to investment. A few economists believed that the US had great investment opportunities, along with highly developed and not overly regulated financial markets, which attracted foreign financial capital to the US. Another explanation for the financial flows into the US was given by Caballero (2010), who supported the view that the world had an excess demand for safe assets. According to Caballero (2010), the US was able to create such assets but, in its effort to do so, exposed the global economy to systemic risk. Bernanke $(2005,2007)$ holds the view that US government deficits and, consequently, CA deficits were the result of a savings glut generated by the Southeastern Asian countries and particularly China. Chinn and Ito (2007) found that CA deficits in the US were the result of government deficits. They also believed that the US suffered from a savings drought and not an investment boom.

Chinn and Ito (2007) supported the twin deficit theory and, in a study of 19 OECD countries, found that a $1 \%$ increase in the government deficit would increase the CA deficit in the range of $0.1 \%$ to $0.5 \% .{ }^{20}$ Bluedorn and Leigh (2011) also found strong evidence of the twin deficit theory in a study of 17 OECD countries from 1978 to 2009. More specifically, they found that a $1 \%$ increase in the government deficit would increase the CA deficit by $0.6 \%$. The effect of fiscal consolidation (reduction in government deficit), however, will be smaller on the CA if the economies are trading partners and if they adjust simultaneously. This was the case for the periphery EA countries that accepted bailouts on the condition that they would accept austerity measures. These austerity measures were meant to generate trade surpluses and growth.

By looking at the US balance of payments accounts (Appendix 2), it is clear that the Financial Account (FA) of the US drastically increased from the 1980s until the

\footnotetext{
${ }^{19}(\mathrm{G}-\mathrm{T})+(\mathrm{I}-\mathrm{S})=(\mathrm{M}-\mathrm{X}) \quad$ is the well-known macroeconomic identity The familiar notation includes the variables:$$
\begin{array}{lll}
\mathrm{G}=\text { Government Expenditure } & \mathrm{T}=\text { Taxes } & \mathrm{I}=\text { Private Investment } \\
\mathrm{S}=\text { Private Saving } & \mathrm{M}=\text { Value of Imports in dollars } & \mathrm{X}=\text { Value of Exports in dollars }
\end{array}
$$

${ }^{20}$ These results are based on 19 industrialized OECD countries for the period 1971 2004.
} 
beginning of the financial crisis. Such increases of financial flows into the US were generated to finance the ever-increasing CA deficit. Figure 1 in Appendix 2 provides ample evidence of this, as the CA of the US is almost a mirror image of the FA. Furthermore, the rising FA indicates that the Feldstein-Horioka paradox did not hold for the US during this period, as domestic saving was no longer highly correlated with domestic investment. This is demonstrated by the massive capital flows to the US. ${ }^{21}$ The CA deficit of the US reached its peak in 2006, only one year before the crisis. It can thus be inferred that the CA deficit caused the global financial crisis or that this was a perfect example of the post-hoc fallacy. The huge global imbalances, measured by the massive CA in the US of over 6\% of GDP, became a great concern to many economists and world leaders. Obstfeld (2012) noted that the CA, although very important for macroeconomic stability, was dwarfed by the capital flows in the world. This claim is very relevant. For example, in 2012, global GDP was approximately 70 trillion US dollars. Yet, in the same year the total volume of traded financial derivatives was approximately 740 trillion US dollars. ${ }^{22}$ Nevertheless, Obstfeld (2012) still believed that CA imbalances should be monitored for stabilization purposes. Furthermore, the IMF, the EU, and the G-20 launched programs aimed at reducing large global and regional trade imbalances.

Two explanations are offered for the causes of the European financial crisis. One view is that the crisis in Europe was the result of excessive borrowing by both the private and public sectors of the southern EA members. According to this argument, soft budgets, excessive borrowing, and low interest rates following the introduction of the euro were the primary causes of the crisis. Many other analysts believe that the crisis was prolonged by poor leadership and a lack of solidarity with the periphery countries. Furthermore, the formation of the SEM and the EMU enabled excessive trade imbalances within the EA countries, which contributed to an increase in public debt of the periphery countries.

Sinn, Buchen, and Wolmerhausen (2011) claimed that both the financial crisis and the EA trade imbalances were caused by an absence of regulations and financial market liability. Low interest rates encouraged the periphery EA countries to borrow excessively from the northern EA countries' banks. ${ }^{23}$ Capital inflows from northern EA countries,

\footnotetext{
${ }^{21}$ See Feldstein and Horioka (1980), and Blanchard and Giavazzi (2002).

${ }^{22}$ Of this 740 trillion US dollars, an amount of 640 trillion US dollars was traded over the counter, meaning there were no public records of these transactions. Such trading of derivatives was a systemic risk to the global economy. See Zestos (2016).

${ }^{23}$ According to them, banks were also equally imprudent in lending to periphery countries.
} 
primarily Germany and France, increased incomes, prices, and imports of the periphery countries. The reduction in periphery EA exports played a crucial role in increasing the public debt-to-GDP ratios. The authors also present data showing that the introduction of the euro caused German savings to be transferred to the periphery EA countries. As a result, Germany generated the lowest investment as a percentage of GDP for the 1995 2008 period among 29 OECD countries.

Schnabl and Zemanek $(2011)^{24}$ provided a diametrically opposite view to Sinn et al. (2011). These authors viewed German unification as the cause of both the 1992 1993 European Monetary System (EMS) exchange rate crisis and the recent CA imbalances in the EA. In support of unification, West Germany contributed an estimated 1.3 trillion euros to the former East Germany from 1991 to 2009. As a result of the unification efforts, Germany's large net international investment position of 250 billion euros in 1990 dropped to zero in $1998 .{ }^{25}$ High German unemployment owing to unification and the influx of workers from former East Germany reduced German wages. The increase in German international competitiveness is attributed to comparatively modest increases in German unit labor costs and the decline in the real exchange rate.

From 1995, Germany experienced a substantial depreciation in its real effective exchange rate. As a result, German CA surpluses increased annually along with the international investment position of the country, which reached 90 billion euros in 2011. For the past 12 months, Germany has generated the largest CA surplus in the world, above that of China. ${ }^{26}$ For the 1995 2011 period, Schnabl and Zemanek (2011) explained that Germany became a financial exporter to the CA deficit EA countries. Foreign capital inflows, wage increases surpassing labor productivity growth, and inflation played a role in the appreciation of the real exchange rates of the periphery EA countries. As a consequence, these countries experienced increases in their CA deficits for several years that ultimately led to unsustainable international indebtedness.

Structural changes in the German economy also played a role. These changes occurred under the leadership of Chancellor Gerhard Schröeder during the 2003 2005 period, when the Social Democratic Party (SPD) implemented unprecedented labor reforms, fiscal austerity programs, and many other supply-side pro-business policies. Most of these new policies and reforms were in line with the Lisbon Agenda, which aimed to transform the EU into the most competitive economy in the world by 2010 .

\footnotetext{
${ }^{24}$ Both authors are from the University of Leipzig, which is located in former East Germany.

${ }^{25}$ See Schnabl and Zemanek (2011).

${ }^{26}$ It amounted to 300.2 billion US dollars or $8.4 \%$ of its GDP for the 12 months prior to July 2016. See The Economist, October $1,2016$.
} 
Although most EU countries did not meet the Lisbon Agenda targets and expectations, Germany did and became an exceptionally competitive economy that generated immense CA surpluses. ${ }^{27}$ However, Chancellor Schröeder and the SPD lost the elections because of labor reforms and the SPD ranked third in the national elections for first time in its history. $^{28}$

Several other authors who have examined trade imbalances in the EA found a close link between CA deficits and capital flows. For example, Schmitz and Von Hagen (2011), by employing Granger causality, found that financial capital moved from the high per capita income EA countries to lower per capita income countries. This flow was interrupted by the crisis, however, as the integration process almost ended. Berger and Nitsch (2012) examined bilateral trade and financial relations among EA countries and found that countries with CA surpluses ended up in a negative net financial position, i.e., they financed the CA deficits of the respective countries.

In another study, Sinn and Wollmershauser (2011) indicated that as private capital flows within the EA dried up during the crisis, the ECB filled the gap by providing credit to deficit countries. This was carried out by transfers between National Central Banks (NCBs) through the ECB target accounts. The authors calculated that the NCBs of the periphery countries created 404 billion euros in central bank money, out of which 390 billion euros were transferred from the German Central Bank, the Bundesbank, by August 2011. According to the authors, this type of arrangement for financing was tantamount to a bailout, such as the ones approved by the European Financial Stability Fund (EFSF) and the European Stability Mechanism (ESM) but without the approval of the national parliaments. ${ }^{29}$

According to the authors, the financial claims on the periphery EA countries that Germany had accumulated during the crisis would pose a major threat to Germany if the EMU were to collapse. They publicized their findings in Germany and turned public opinion against the periphery countries. According to De Grauwe and Ji (2012), such fears were unfounded and based on the authors' misunderstanding of the Target2 payment system. De Grauwe and Ji (2012) explained that Target2 claims and liabilities began rising during a period in which EA deficits of periphery countries were

\footnotetext{
${ }^{27}$ Germany, regardless of the historical episode discussed here, has been a technologically advanced country and has had a highly productive labor force in the manufacturing sector. High labor productivity, however, was a necessary but not sufficient condition for the country to be internationally competitive. Therefore, the labor reforms and the unification substantially reduced real wages which helped Germany become an internationally competitive economy.

${ }^{28}$ See Zestos and Williamson (2012).

${ }^{29}$ Sinn and Wollmershauser (2011)
} 
decreasing. Thus, the main reason for the unprecedented increase in the Target 2 balances of NCBs was the panic of investors who had been changing the composition of their portfolios by replacing risky assets with less risky ones and not the increased deficits of periphery countries. De Grauwe and Ji (2012) concluded that these shifts in investment portfolios did not pose an inflationary risk to Germany. In the event of an EMU collapse speculators would move money to German banks in order to receive a more favorable exchange rate for their euros. Germany, however, to avoid inflation, could simply refuse to pay back foreign euro deposits in the national German currency to non-German residents.

Stockhammer (2011) claimed that European imbalances were the result of German wage suppression. He argued that one country's CA surplus is another's deficit; therefore, for the periphery countries to reduce their deficits, core countries (particularly Germany) would have to rebalance through wage increases. This policy has been recommended by many economists as it will increase incomes in core economies and thus increase demand for periphery countries' imports. Such a policy is not likely to be adopted, however, because the EMU places the burden of adjustment on the CA deficit countries via internal devaluation. This is because the ECB has a deflationary bias, and wage increases in core countries, such as Germany, would cause inflation. Using econometric techniques with panel data, Belke and Dreger (2013) examined the determinants of CA imbalances in the EA. They found that a lack of competitiveness in the periphery countries was the main reason for trade imbalances within the EA. The authors claim that deterioration of competitiveness is not possible for the core EA countries because such deterioration would reduce the wealth of the entire EA. Therefore, they conclude that only the periphery countries must correct the imbalances via internal devaluation, i.e., impoverization.

Several economists indicate the lack of a corrective adjustment mechanism in the EMU to reduce trade imbalances. For example, Dellas and Tavlas (2012) compared the adjustment mechanism of the balance of payments under the gold standard (the specieflow mechanism) to the current EMU regime. Under the latter, trade imbalances were perpetuated by the false perception of an absence of credit risk. This perception was largely held because of an implicit assumption of a bailout from the EU.

Chen, Milesi-Ferretti, and Tressel (2013) found that periphery countries' easy access to credit through financial institutions of the core countries led to the appreciation of the real effective exchange rate of the periphery countries. This, coupled with the rapid increase in the nominal value of the euro, contributed to the loss of competitiveness of 
the deficit countries and to large trade imbalances.

Finally, Young and Semmler (2011) argued that Germany-in the years leading up to the crisis-became more inward looking, pursuing more closely its own nationalistic interests. Their conclusion was based on how Germany handled the crisis. It is highly likely that the German approach may set a precedent for other countries to act in a similar way, placing national interests above common interests. Such an approach could also threaten the long-term viability of the European project.

\section{Time Series Analysis}

Trade imbalances among southern and northern EA countries arose after the launch of the EMU in 1999 and increased until 2008, the year the financial crisis began spreading to Europe. To investigate the hypothesis that the current European sovereign debt crisis was caused by macroeconomic trade imbalances among the northern and southern EA countries, we estimate two bivariate and one trivariate VECMs and employ them to perform Granger causality tests.

The first variable is the annual rate of growth of the weighted average of the public debt-to-GDP ratio of four southern EA countries and Ireland, denoted as the Southern Public Debt Growth (SPDGR). ${ }^{30}$ The second variable is the weighted average of the CAs of five northern EA countries, denoted as the Northern Weighted Average Current Account $(N W A C A){ }^{31}$ The third variable is the weighted average GDP growth of the southern EA countries, denoted as the Southern GDP Weighted Average (SGDPWA).

We estimate the two bivariate and one trivariate VECMs using annual data for the 1977 2011 period. Before estimating the VECMs, we performed unit root tests to investigate the stability properties of the three variables. The three variables were found to meet the dynamic stability properties required to test for cointegration. Since evidence of cointegration exists, we proceeded with the estimation of the VECMs. Within the framework of the estimated VECMs, we performed Granger causality tests to ascertain

\footnotetext{
${ }^{30}$ The weights of the countries are calculated based on the share of each of the five countries' GDP to their total GDP. The growth of the weighted debt-to-GDP ratio variable is a more accurate representation of the five countries' public debt-to-GDP ratio because it is not biased as it would have been if no weights were employed.

${ }^{31}$ The weights of $N W A C A$ are calculated in the same way as in the first variable.
} 
the direction and degree of causality. ${ }^{32}$ The data are drawn from The Conference Board Total Economy Database.

\section{A. Unit root test results}

The Appendix 1 reports the unit root results for all the time series variables. According to the Augmented Dickey-Fuller (ADF) and the Phillips-Perron (PP) tests, the estimated results satisfy the stability criteria for the variables to be employed in the cointegration tests. To determine the optimum number of lagged differences to be included in the estimated unit root equation of the ADF test, we use both the Schwarz and the Akaike Information Criteria (SBC, AIC). The variables, in the vast majority of the tests, are found to be non-stationary in levels and stationary in first differences.

\section{B. Bivariate Vector Error Correction Model}

Equation (1) and Equation (2) represent a bivariate VECM in endogenous variables $\mathrm{X}$ and $\mathrm{Y}$. Variable $\mathrm{X}$ represents the annual rate of growth of the weighted average of the public debt-to-GDP ratio of the four southern EU countries and Ireland, denoted as the $S P D G R$. In the first bivariate model, variable $\mathrm{Y}$ is the weighted average of the northern EA countries' CA, denoted by $N W A C A$.

$$
\begin{aligned}
& \Delta X_{t}=\alpha_{1}+\alpha_{2} t+\alpha_{x} E C_{t-1}+\sum_{i=1}^{r_{1}} \alpha_{1 i} \Delta X_{t-i}+\sum_{i=1}^{s_{1}} \beta_{1 i} \Delta Y_{t-i}+\varepsilon_{1 t} \\
& \Delta Y_{t}=\beta_{1}+\beta_{2} t+\beta_{y} E C_{t-1}+\sum_{i=1}^{r_{2}} \alpha_{2 i} \Delta X_{t-i}+\sum_{i=1}^{s_{2}} \beta_{2 i} \Delta Y_{t-i}+\varepsilon_{2 t}
\end{aligned}
$$

The left-hand side variables of the VECM in Equation (1) and Equation (2) are expressed in terms of first differences. The right-hand sides of each equation include an optimum number of lagged differences for each of the two variables. In addition to

\footnotetext{
${ }^{32}$ See Granger (1988).

${ }^{33}$ See https://www.conference-board.org/data/economydatabase/

${ }^{34}$ For example, the unit-root test for the CAGERM variable, in its first difference, is an exception. The $p$-values for the case of the constant and constant and trend are 0.088 and 0.23 , respectively. To reject non-stationarity from these two tests, at any level of significance, the $p$-values should have been close to zero.
} 
the lagged differences, each equation includes the one-period lagged error term of the cointegrating equation denoted by $E C_{t-1}$. The one-period lagged error term $E C_{t-1}$ was constructed as a vector of values based on the cointegration equation and the time series data of the variables $X$ and $Y$. Furthermore, each equation includes a constant, $\alpha_{1}$ and $\beta_{1}$, respectively, and a time trend variable $t$. The error term in each equation is assumed to be white noise. The error terms in Equation (1) and Equation (2) are denoted by $\varepsilon_{1 t}$ and $\varepsilon_{2 t}$, respectively. Three different types of Granger causality tests were performed on each of the two equations of the bivariate VECM, based on Granger (1988). We test for long-run causality by formulating the null hypothesis that the coefficient of the one-period lagged error term of the cointegration equation $E C_{t-1}$, is zero. This test examines whether the relevant right-hand side variables in each equation have a long-run linear relation with the left-hand side variable and, thus, Granger cause this variable. In Equation (1), this test is performed with the null hypothesis $H_{0}: \alpha_{x}=0$, versus $H_{A}: \alpha_{x} \neq 0$. A similar test is performed for Equation (2).

Two types of short-run Granger causality tests are also performed for each equation. The first test is carried out by setting the coefficients of all lagged differences of the relevant right-hand side variable in each equation equal to zero. For example, in Equation (1), a test for short-run non-causality from $Y$ to $X$ is carried out by testing whether the coefficients of the lagged differences of the $Y$ variable are jointly equal to zero, i.e., $H_{0}$ : $\beta_{11}=\beta_{12}=\ldots . .=\beta_{1} s_{1}=0$. The alternative hypothesis of short-run non-Granger causality from $Y$ to $X$ is stated as $H_{a}: \beta_{11} \neq \beta_{12} \neq \ldots \ldots \neq \beta_{1} s_{1} \neq 0$. We also perform a similar test for short-run non-causality from $X$ to $Y$ in Equation (2) by setting the respective coefficients of the lagged differences of $X$ simultaneously equal to zero, $H_{0}: \alpha_{21}=\alpha_{22}=\ldots . .=\alpha_{2} r_{2}=0$.

The second short-run non-causality test is similar to the first short-run causality test discussed above. In the null hypothesis of this test for overall causality, the coefficient of the one-period lagged error term, along with the coefficients of all order lagged differences of each relevant right- hand side variable, are set equal to zero. For example, in Equation (1) a test for overall short-run non-causality from variable $Y$ to variable $X$ is stated as $H_{0}: \alpha_{x}=\beta_{11}=\beta_{12}=\ldots . . \beta_{1} s_{1}=0$. The alternative hypothesis of overall short-run non-causality from $Y$ to $X$ is stated as $H_{a}: \alpha_{x} \neq \beta_{11} \neq \beta_{12} \neq \ldots \ldots \beta_{1} s_{1} \neq 0$. A similar test for overall short-run non-causality from $X$ to $Y$ is performed in Equation (2). 


\section{First bivariate model}

In Table 1, we report the results of the cointegration test based on the Johansen methodology $(1991,1995)$. According to these results, and based on both $\lambda_{\max }$ and $\lambda_{\text {trace }}$ statistics, there exists statistical evidence for one cointegrating vector at the $5 \%$ level of significance.

Table 1. Johansen cointegration tests for SPDGR and NWACA

\begin{tabular}{|c|c|c|c|c|c|c|c|}
\hline $\mathbf{H}_{\mathbf{0}}$ & Eigen value & $\boldsymbol{\lambda}_{\max }$ & $\begin{array}{c}\text { Critical value } \\
\text { at 5\% }\end{array}$ & $\boldsymbol{p}$-value & $\boldsymbol{\lambda}_{\text {trace }}$ & $\begin{array}{c}\text { Critical value } \\
\text { at 5\% }\end{array}$ & $\boldsymbol{p}$-value \\
\hline $\mathrm{r}=0$ & 0.493 & 20.392 & 19.387 & 0.036 & 25.581 & 25.872 & 0.054 \\
\hline $\mathrm{r} \leq 1$ & 0.159 & 5.189 & 12.517 & 0.569 & 5.189 & 12.517 & 0.569 \\
\hline
\end{tabular}

(Note) SPDGR: Southern Public Debt-to-GDP Ratio Growth Rate (weighted average)

NWACA: Northern Weighted Average Current Account

Equation (3) below is the cointegrating equation of the two variables, which shows that $S P D G R$ and NWACA are positively related. This relation indicates that when the weighted average of the CA balances of the five northern EA countries (NWACA) increases, the weighted average of the rate of growth of the public debt-to-GDP ratio of the five southern EA countries also increases. This important result suggests that the rising weighted average sovereign debt-to-GDP ratio of the southern EA countries is closely related to trade imbalances between the two groups and, specifically, to the weighted average of trade surpluses of the northern EA countries. The rationale of this relation is straightforward. When the periphery countries generate a series of CA deficits, such deficits are financed via increased borrowing from abroad, thus increasing the foreign indebtedness of these countries. A constant and a negative trend are present in the cointegration equation.

$$
\begin{array}{cc}
S P D G R=8.395628+6.896180 \times & N W A C A-0.890372 \times \text { Trend } \\
& 1.835844 \\
(3.756) * * * & .19381 \\
& (-4.594) * * *
\end{array}
$$

The estimated VECM between SPDGR and NWACA is reported in Equation (4) and 
Equation (5). This model includes, on the left-hand side, the first difference of each of the two variables denoted by $D(S P D G R)$ and $D(N W A C A)$. On the right-hand side, each equation includes a constant, the one-period lagged error correction term $E C_{t-1}$, and four lagged differences of the two variables $\sum \triangle S P D G R$ and $\sum \triangle N W A C A .^{35}$

We perform three different types of Granger causality tests using the estimated model in Equation (4), and Equation (5). The test results are shown in Table 2. First, the longrun Granger causality test was performed using a $t$-test on the $E C_{t-1}$ term in each of the two equations. This test shows strong statistical evidence for long-run causality from the northern EA countries' weighted average CA (NWACA) to the southern countries' weighted average public debt-to-GDP ratio growth rate $(S P D G R)$. This is shown by the statistically significant (at the $1 \%$ level) one-period lagged error correction term, $E C_{t-1}$. In contrast, Equation (5) shows that there is no statistical evidence for long-run reverse causality from the SPDGR to the NWACA. This implies that the weighted growth of southern EA countries' public debt-to-GDP ratio does not Granger cause the weighted CA surpluses of the northern EA countries.

The short-run causality tests provide further statistical evidence of Granger causality from $N W A C A$ to SPDGR. This is shown in Equation (4) by the test for overall causality indicated by the $F_{2}$ statistic, which is statistically significant at the $1 \%$ level. The short-run causality tests indicate that there is no evidence of short-run causality from $S P D G R$ to NWACA. This is revealed in Equation (5) where none of the $F$-statistics are statistically significant. We conclude that evidence exists for both short- and long-run Granger causality from the northern CA surpluses to the southern public debts, but no evidence of reverse causality is supported.

\footnotetext{
${ }^{35}$ The two variables denote the sum of all higher order (four in this model) lagged differences. They are reported as a sum here to write the model in a more compact form.
} 
Table 2. Vector error correction model for SPDGR and NWACA

\begin{tabular}{|c|c|c|c|c|c|c|c|}
\hline & Variable & $\boldsymbol{C}$ & $\boldsymbol{E C}_{\boldsymbol{t}-1:}$ & $\sum_{i=1}^{4} \Delta \boldsymbol{S P D G R}$ & $\begin{array}{c}\boldsymbol{F}_{1} \\
\text { (overall causality) }\end{array}$ & $\sum_{i=1}^{4} \Delta \boldsymbol{N W C A}$ & $\begin{array}{c}\boldsymbol{F}_{2} \\
\text { (overall causality) }\end{array}$ \\
\hline $\begin{array}{c}\text { Equation } \\
(4)\end{array}$ & $D(S P D G R)$ & 1.705 & -.893 & 1.307 & {$[4.902]^{* * *}$} & -17.266 & {$[4.11]^{* * *}$} \\
\hline & .831 & 0.203 & & & & {$[0.269]$} & \\
\hline $\begin{array}{c}\text { Equation } \\
(5)\end{array}$ & $D(N W A C A)$ & 0.067 & -0.065 & -0.054 & {$[0.357]$} & 0.333 & {$[0.984]$} \\
\hline & $(2.052)^{*}$ & $(-4.39)^{* * *}$ & {$[2.301]^{*}$} & & & \\
\hline & $(.130$ & 0.132 & & & {$[0.860]$} & \\
\hline
\end{tabular}

(Notes) (i) ***,**,* denote significance at the 1, 5, and 10\% levels respectively.

(ii) $C$ : Constant, $E C_{t-1:}$ : One-period lagged error correction term, SPDGR: Southern public debt-to GDP growth rate (weighted average), $N W A C A$ : Northern weighted average current account

(iii) Values in parentheses () denote $t$-tests, values in brackets [] denote $F$-tests.

\section{Second bivariate model}

We estimated a second VECM to examine possible causal relations between the average southern EA public debt-to-GDP ratio growth rate (SPDGR), and the German CA-to-GDP ratio (CAGERM). With this model, we investigate whether German trade surpluses Granger cause southern EA public debt growth. We also check for reverse causality from SPDGR to CAGERM. The unit root tests for CAGERM are reported in Appendix 1. According to these tests, the variable CAGERM is non-stationary in levels, but stationary in first differences, thus allowing us to proceed with the cointegration test.

The cointegration test shown in Table 3 provides evidence of cointegration between the southern public debt-to-GDP ratio growth rate $(S P D G R)$ and the German CA-toGDP ratio (CAGERM). The Johansen cointegration test supports one cointegrating equation at the $5 \%$ level of significance based both on the $\lambda_{\max }$ and $\lambda_{\text {trace }}$ statistics. 
Table 3. Johansen cointegration tests for SPDGR and CAGERM

\begin{tabular}{|c|c|c|c|c|c|c|c|}
\hline $\mathbf{H}_{\mathbf{0}}$ & Eigen value & $\boldsymbol{\lambda}_{\max }$ & $\begin{array}{c}\text { Critical value } \\
\text { at 5\% }\end{array}$ & $\boldsymbol{p}$-value & $\boldsymbol{\lambda}_{\text {trace }}$ & $\begin{array}{c}\text { Critical value } \\
\text { at 5\% }\end{array}$ & $\boldsymbol{p}$-value \\
\hline $\mathrm{r}=0$ & 0.529115 & 27.981 & 25.872 & 0.017 & 22.594 & 19.387 & 0.027 \\
\hline $\mathrm{r} \leq 1$ & 0.164353 & 5.386 & 12.518 & 0.542 & 5.386 & 12.518 & 0.542 \\
\hline
\end{tabular}

(Note) SPDGR: Southern public debt-to-GDP growth rate (weighted average)

CAGERM: Current account of Germany

According to the cointegration Equation (6) below, there exists a positive and statistically significant relation between SPDGR and CAGERM. ${ }^{36}$

$$
\begin{aligned}
& \text { SPDGR }=8.023494+.070895 \times C A G E R M-.484521 \times \text { Trend } \\
& .082777 \quad 01777 \\
& (3.990140) * * * \quad(-5.85363) * * *
\end{aligned}
$$

Since the Johansen test provides statistical evidence of cointegration, we proceed with the VECM estimation, which is reported in Table 4. The estimated VECM between $S P D G R$ and CAGERM is reported in Equation (7) and Equation (8). This model includes, on the left-hand side, the first difference of each of the two variables denoted by $D(S P D G R)$ and $D(C A G E R M)$. On the right-hand side, each equation includes a constant, the one-period lagged error term $E C_{t-1}$, and four lagged differences of the two variables $\sum \triangle S P D G R$ and $\sum \triangle C A G E R M{ }^{37}$

The estimated VECM shown below indicates statistical evidence of long-run causality from the German CA surplus to the growth of the public debt-to-GDP ratio of the periphery countries. This is indicated in Equation (7) from the $t$-value of the one-period lagged error correction term $E C_{t-1}$, which is statistically significant at the $1 \%$ level. Furthermore, there is evidence of short-run causality from the CAGERM to $S P D G R$. This is indicated by the $F$-statistic below the $\sum \triangle C A G E R M$ term. ${ }^{38}$ Evidence for overall causality is also supported by the value of the $F_{2}$ statistic, which is significant

\footnotetext{
${ }^{36}$ This means that as Germany's CA increases, so does the public debt-to-GDP ratio of the periphery countries.

${ }^{37}$ The two variables denote the sum of all higher order (four in this model) lagged differences. They are reported as a sum here to write the model in a more compact form.

${ }^{38}$ This is a stronger result than that of the first model because in the first model, there was no evidence for short-run causality from the northern CA surplus to the southern public debt.
} 
at the $1 \%$ level as well. The public debt growth of the southern EA countries (SPDGR), however, does not Granger cause the German CA-to-GDP ratio (CAGERM). Equation (8) confirms this result as none of the coefficients are statistically significant. This constitutes additional evidence that the public debt of the southern EA countries does not Granger cause the German CA surplus.

Table 4. Vector error correction model for SPDGR and CAGERM

\begin{tabular}{|c|c|c|c|c|c|c|c|}
\hline & Variable & $C$ & $E C_{t-1}$ & $\sum_{i=1}^{4} \Delta S P D G R$ & $\begin{array}{c}F_{1} \\
\text { (overall causality) }\end{array}$ & $\sum_{i=1}^{4} \Delta C A G E R M$ & $\underset{\text { (overall causality) }}{\boldsymbol{F}_{2}}$ \\
\hline \multirow[t]{3}{*}{$\begin{array}{c}\text { Equation } \\
(7)\end{array}$} & $D(S P D G R)$ & 1.444 & -1.175 & 1.54 & {$[4.72]^{* * *}$} & -0.26 & {$[4.56] * * *$} \\
\hline & & -0.806 & -0.268 & & & & \\
\hline & & ( 1.79$)$ & $(-4.38) * * *$ & {$[2.74]$} & & {$[2.23]^{* * *}$} & \\
\hline \multirow[t]{3}{*}{$\begin{array}{c}\text { Equation } \\
(8) \\
\end{array}$} & $D(C A G E R M)$ & 2.236 & 1.568 & -0.952 & {$[0.203]$} & 2.481 & [0.547] \\
\hline & & -6.48 & -2.155 & & & & \\
\hline & & $(0.345)$ & $(0.727)$ & [0.083] & & {$[1.7]$} & \\
\hline
\end{tabular}

(Notes) (i) *** denotes significance at the $1 \%$ level.

(ii) $C$ : Constant, $E C_{t-1:}$ : One-period lagged error correction term, SPDGR: Southern public debt-to GDP growth rate (weighted average), CAGERM: Current account of Germany

(iii) Values in parentheses () denote $t$-tests, values in brackets [] denote $F$-tests.

\section{E. Trivariate model}

Lastly, we estimate a trivariate VECM that adds endogenous variable $Z$ - the weighted average GDP growth of the southern EA countries - to the previous model. This variable is denoted as the southern GDP weighted average ( $S G D P W A)$. The variables $X$ and $Y$ are defined as they were for the first bivariate VECM. Equation (9), Equation (10), and Equation (11) represent this trivariate VECM in endogenous variables $X, Y$, and $Z$. 


$$
\begin{aligned}
& \Delta X_{t}=\alpha_{1}+\alpha_{2} t+\alpha_{x} E C_{t-1}+\sum_{i=1}^{r_{1}} \alpha_{1 i} \Delta X_{t-i}+\sum_{i=1}^{S_{1}} \beta_{1 i} \Delta Y_{t-i}+\sum_{i=1}^{k_{1}} \gamma_{1 i} \Delta Z_{t-i}+\varepsilon_{1 t} \\
& \Delta Y_{t}=\beta_{1}+\beta_{2} t+\beta_{y} E C_{t-1}+\sum_{i=1}^{r_{2}} \alpha_{2 i} \Delta X_{t-i}+\sum_{i=1}^{S_{2}} \beta_{2 i} \Delta Y_{t-i}+\sum_{i=1}^{k_{2}} \gamma_{2 i} \Delta Z_{t-i}+\varepsilon_{2 t} \\
& \Delta Z_{t}=\gamma_{1}+\gamma_{2} t+\gamma_{z} E C_{t-1}+\sum_{i=1}^{r_{3}} \alpha_{3 i} \Delta X_{t-i}+\sum_{i=1}^{S_{3}} \beta_{3 i} \Delta Y_{t-i}+\sum_{i=1}^{k_{3}} \gamma_{3 i} \Delta Z_{t-i}+\varepsilon_{3 t}
\end{aligned}
$$

The weighted average of the GDP of the southern EA countries was included as a third variable in the VECM to reinforce the empirical findings and to demonstrate that the results are robust to the model specification. The rationale for its inclusion is that if acute trade imbalances cause over-indebtedness, then it is likely that CA surpluses in the northern EA countries might affect economic growth of the periphery countries. In such a case, recession in the southern EA countries would be at least partly attributed to trade imbalances.

According to unit root tests, the third variable $S G D P W A$ is non-stationary in levels but stationary in first difference. ${ }^{39}$ The three variables were tested for cointegration. According to the trace statistic in Table 5, the three variables are cointegrated at the 5\% level of significance.

Table 5. Johansen cointegration tests for SPDGR, SGDPWA, and NWACA

\begin{tabular}{|c|c|c|c|c|c|c|c|}
\hline $\mathbf{H}_{\mathbf{0}}$ & Eigen Value & $\boldsymbol{\lambda}_{\max }$ & $\begin{array}{c}\text { Critical value } \\
\text { at 5\% }\end{array}$ & $\boldsymbol{p}$-Value & $\boldsymbol{\lambda}_{\text {trace }}$ & $\begin{array}{c}\text { Critical value } \\
\text { at 5\% }\end{array}$ & $\boldsymbol{p}$-Value \\
\hline $\mathrm{R}=0$ & 0.442 & 19.234 & 22.300 & 0.127 & 35.699 & 35.193 & 0.044 \\
\hline $\mathrm{r} \leq 1$ & 0.246 & 9.314 & 15.892 & 0.401 & 16.464 & 20.262 & 0.154 \\
\hline
\end{tabular}

(Note) SPDGR: Southern Public Debt-to-GDP Growth Rate (weighted average)

$S G D P W A$ : Southern GDP Weighted Average

NWACA: Northern Weighted Average Current Account

According to the cointegrating Equation (12) below, there again exists a positive relation between the northern $\mathrm{CA}$ surpluses $(N W A C A)$ and southern weighted average

\footnotetext{
${ }^{39}$ The result of the unit root test for this variable is also included in Appendix 1.
} 
public debt-to-GDP ratio growth rate $(S P D G R)$. A negative relation exists between the southern EA countries' weighted average GDP and the growth of the public debt of the southern EA countries (SPDGR), indicating that growth is necessary to reduce southern EA public debts.

$$
\begin{array}{cc}
S P D G R=40.1071-0.049254 \times(S G D P W A)+ & 3.619645 \times(N W A C A) \\
.00988 & 1.25232 \\
(-4.98429) * * * & (2.89034) * * *
\end{array}
$$

Table 6 reports the estimated trivariate VECM and the three Granger causality tests. This model includes, on the left-hand side, the first difference of each of the three variables denoted by $\mathrm{D}(S P D G R), \mathrm{D}(S G D P W A)$, and $\mathrm{D}(N W A C A)$. On the right-hand side, each equation includes a constant, the one-period lagged error term $E C_{t-1}$, and two lagged differences of the three variables $\sum \triangle S P D G R, \sum \triangle S G D P W A$, and $\sum \triangle N W A C A$.

According to the estimated model, there exists statistical evidence in Equation (13) for long-run causality from southern GDP weighted average (SGDPWA) and NWACA to $S P D G R$, at the $5 \%$ level of significance. There is also evidence of overall causality from $N W A C A$ to SPDGR and from SGDPWA to SPDGR at the $10 \%$ significance level. No evidence of any type of Granger causality exists in Equation (14) from SPDGR and $N W A C A$ to $S G D P W A$. This suggests that neither trade imbalances nor public debt in the EA Granger caused the recession in the periphery countries (SGDPWA); it is highly likely other factors affected GDP of the southern EA countries. Equation (15) provides weak statistical evidence that public debt and GDP growth of southern EA countries Granger caused the $N W A C A$. This is indicated by the $t$-value on the $E C_{t-1}$ term which is significant at the $10 \%$ level. No short-run Granger causality was found from SPDGR or $S G D P W A$ to NWACA. 
Table 6. Estimated Vector Error Correction Model for SPDGR, SGDPWA, and NWACA

\begin{tabular}{|c|c|c|c|c|c|c|c|c|c|}
\hline & & C & $E C_{t-1:}$ & $\sum_{i=1}^{2} \triangle S P D G R$ & $\begin{array}{c}F_{1} \\
\text { (overall } \\
\text { ausality) }\end{array}$ & $\sum_{i=1}^{2} \Delta S G D P W$ & $\begin{array}{c}F_{2} \\
\text { (overall } \\
\text { ausality) }\end{array}$ & $\sum_{i=1}^{2} \Delta N W A C A$ & $\begin{array}{c}\underset{3}{F_{3}} \\
\text { (overall } \\
\text { causality) }\end{array}$ \\
\hline \multirow[t]{3}{*}{$\begin{array}{c}\text { Equation } \\
(13)\end{array}$} & $D(S P D G R)$ & 2.7193 & -0.663 & -.2236 & {$[3.299]^{* *}$} & -0.16178 & $\mid[2.519]^{*}$ & -3.18633 & [2.432]* \\
\hline & & 1.5549 & 0.2657 & & & & & & \\
\hline & & (1.7488) & $(-2.4955) * *$ & [0.8859] & & [1.5991] & & [1.7675] & \\
\hline \multirow[t]{3}{*}{$\begin{array}{c}\text { Equation } \\
\text { (14) }\end{array}$} & $D(S G D P W A)$ & 5.7667 & 0.6008 & 0.438852 & {$[0.248]$} & 0.4806 & [1.225] & 2.124903 & {$[0.642]$} \\
\hline & & 5.988 & 1.0232 & & & & & & \\
\hline & & $(0.963)$ & $(0.5873)$ & [0.104] & & [1.8179] & & [0.9129] & \\
\hline \multirow[t]{3}{*}{$\begin{array}{c}\text { Equation } \\
(15)\end{array}$} & $D(N W A C A)$ & -0.1438 & 0.0638 & -0.04144 & {$[1.225]$} & 0.0163 & [1.280] & 0.07054 & [2.032]* \\
\hline & & 0.1951 & 0.0333 & & & & & & \\
\hline & & $(-0.7367)$ & $(1.9126)^{*}$ & {$[0.35799]$} & & {$[1.0282]$} & & {$[0.7145]$} & \\
\hline
\end{tabular}

(Notes) (i) ** denotes significance at the $5 \%$ level, and * denotes significance at the $10 \%$ level.

(ii) $C$ : Constant, $E C_{t-1:}$ : One-period lagged error correction term, SPDGR: Southern public debt-to GDP growth rate (weighted average), SGDPWA: Southern GDP weighted average, NWACA: Northern weighted average current account

(iii) Values in parentheses () denote $t$-tests, values in brackets [] denote $F$-tests.

\section{Conclusions}

The public debt of the southern EA countries and Ireland increased significantly during the European financial crisis. The EMU has largely been an economic boon for Europe since it has supported an established large market, which increased trade and freed capital and labor mobility. However, an unintended consequence of the EMU has been credit expansion and excessive borrowing by the periphery EA countries that induced large trade deficits. The standard policy prescriptions to resolve such imbalances - price and real wage adjustment, fiscal austerity (for deficit countries), and a common monetary policy_ offered little or no redress owing to structural impediments 
in the EMU and flawed EU policies imposed by Germany and the IMF.

Before the crisis, public debt levels were sustainable. However, when revelations concerning the extent of Greek public deficit emerged, markets punished Greece with unprecedented increases in risk premia on its interest rates. Notably, the Greek debtto-GDP ratio in 2007 2008 was not much higher than its past values, from 1993, of approximately $100 \%$; we can infer that if the leaders of two consecutive Greek governments had not started a Peloponnesian war by accusing each other of fabricating fiscal data, the crisis may never have erupted. One could argue that over-reaction in the debt markets triggered a damaging cycle of higher interest rates and slow and negative growth. The periphery countries had to discover this the hard way, with severe recession-depression in the case of Greece and Spain - and precipitous increases in unemployment and poverty.

The crisis could have been avoided, but national leaders failed to act correctly and promptly. In our view, an appropriate policy response to the crisis would have been the formation of a complete fiscal and a banking union via more integration. The crisis could have been prevented if the EU leaders had demonstrated the necessary determination to resolve the crisis, instead of pressing the periphery to further impoverish their people.

In this study, we modeled the endogenous, long-term equilibrium relationship between CA surpluses and public debt with a bivariate VECM. The empirical results of this study indicate that CA surpluses in the northern EA countries caused increases in the periphery public debt. Reverse causality from public debt of the periphery countries to the CA balance of the northern EA countries was not supported in the two bivariate models.

To check for robustness of the model and the sensitivity of the results to model specification, we estimated a trivariate VECM. This model employed a third variable in addition to the two used in the first model. This variable was the weighted average GDP of the southern EA countries. The estimated results of this model also support the empirical findings of the two bivariate models and, in addition, show that trade imbalances did not cause the southern EA countries' GDP.

Future research should examine other possible causes of the periphery public overindebtedness and the recession that followed. The massive capital flight from periphery countries to safer investment environments certainly stymied growth. Research that features financial flows variables in the VECM along with the rate of growth of real GDP of the periphery countries could complement this study and offer valuable insights. 
Received 1 August 2016, Revised 13 October 2016, Accepted 25 October 2016

\section{References}

Alessandrini, Pietro, Michele Fratianni, Andrew H. Hallett, and Andrea F. Presbitero. "External Imbalances and Financial Fragility in the Euro Area." Open Economies Review 25 (2014): 3-34.

Belke, Ansgar, and Christian Dreger. "Current Account Imbalances in the Euro Area: Does Catching up Explain the Development?" Review of International Economics 21 (2013): 6-17.

Berger, Helge, and Volker Nitsch. "Bilateral Imbalances in Europe." CESifo Economic Studies (2012). Accessed January 5, 2014. doi: 10.1093/cesifo/ifs033.

Bernanke, Ben. "Global Imbalances: Recent Developments and Prospects." Presentation at the Bundesbank Lecture, Berlin, Germany, September 11, 2007.

Blanchard, Oliver, and Francesco Giavazzi. "Current Account Deficits in the Euro Area: The End of the Feldstein-Horioka Puzzle?" Brookings Papers on Economic Activity 2 (2002): 147-209.

Bluedorn, John, and Daniel Leigh. "Revisiting the Twin Deficits Hypothesis: The Effect of Fiscal Consolidation on the Current Account." IMF Economic Review 59 (2011): 582602.

Caballero, Ricardo. "A Caricature (Model) of the World Economy." MIT Department of Economics Working Paper No. 10-17 (2010). Accessed March 4, 2016. http://dx.doi. org/10.2139/ssrn. 1724897.

Chen, Ruo, Gian M. Milesi-Ferreti, and Thierry Tressel. "External Imbalances in the Eurozone." Economic Policy 73 (2013): 101-142.

Chinn, Menzie, and Hiro Ito. "Current account balances, financial development and institutions: Assaying the world 'saving glut'." Journal of International Money and Finance 26 (2007): 546-569.

Darvas, Zsolt. "Intra-Euro Rebalancing is Inevitable, but Insufficient." Bruegel Policy 
(2012). Accessed July 25, 2013 from http://bruegel.org/wp-content/uploads/imported/ publications/pc_2012_15_2_.pdf

De Grauwe, Paul, and Yuemei Ji. "What Germany should fear most is its own fear: An analysis of Target 2 and current account imbalances." Centre for European Policy Studies 368 (2012).

Dellas, Harris, and George S. Tavlas. "The road to Ithaca: the Gold Standard, the Euro and the origins of the Greek sovereign debt crisis." Bank of Greece 149 (2012).

Feldstein, Martin, and Charles Horioka. "Domestic Saving and International Capital Flows." The Economic Journal 90 (1980): 314-329.

Granger, Clive W. "Some Recent Developments in a Concept of Causality." Journal of Econometrics 39 (1988): 199-211.

Johansen, Soren. "Estimation and Hypothesis Testing of Cointegration Vectors in Gaussian Vector Autoregressive Models.” Econometrica 59 (1991): 1551-1580.

Johansen, Soren. Likelihood-based Inference in Cointegrated Vector Autoregressive Models. Oxford: Oxford University Press, 1995.

Lane, Philip R. "The European Sovereign Debt Crisis." The Journal of Economic Perspectives 26 (2012): 49-67.

"Markets and Data." The Economist, October 15, 2016: 17-23.

Obstfeld, Maurice. "Does the Current Account Still Matter?" American Economic Review 102 (2012): 1-23.

Schmitz, Birgit, and Jurgen Von Hagen. "Current Account Imbalances and Financial Integration in the Euro Area." Journal of International Money and Finance 30 (2011): $1676-1695$.

Schnabl, Gunther, and Holger Zemanek."Inter-temporal savings, current account trends and Asymmetric Shocks in a Heterogeneous European Monetary Union." Review of European Economic Policy 46 (2011): 153-160.

Sinn, Hans-Werner, Teresa Buchen, and Timo Wollmershäuser. "Trade Imbalances: Causes, Consequences, and Policy Measures." In Reform of the International Monetary System: The Palais Royal Initiative edited by Boorman, Jack, and Andre Icard 321-342. London: SAGE Publications Ltd, 2011. 
Sinn, Hans-Werner, and Timo Wollmershäuser. "Target Loans, Current Account Balances and Capital Flows: the ECB's Rescue Facility." National Bureau of Economic Research, Working Paper 17626 (2011).

Stockhammer, Engelbert. "Peripheral Europe's Debt and German Wages: the Role of Wage Policy in the Euro Area." International Journal of Public Policy 7 (2011): 83-96.

“The Conference Board Total Economy Database." Accessed December 27, 2015. https://www.conference-board.org/data/economydatabase/

Yin, Ling, George K. Zestos, and Leo Michelis. "Economic Convergence in the European Union.” Journal of Economic Integration 18 (2003): 188-213.

Young, Brigitte, and Willi Semmler. "The European Sovereign Debt Crisis Is Germany to Blame?” German Politics and Society 29 (2011): 1-24.

Zestos, George K. European Monetary Integration: The Euro. Mason: Thompson Southwestern, 2006.

Zestos, George K. The Global Financial Crisis: From U.S Subprime Mortgages to European Sovereign Debt. New York: Routledge, 2016.

Zestos, George K., and Michael Williamson. "German Rigidity: An Obstacle to the Resolution of the European Crisis." Journal of Regional \& Socio-Economic Issues 2 (2012): 5-20.

Zestos, George K., and Ling Yin. "Global Economic Convergence." International Journal of Economic Research 6 (2009): 175-203. 
$j e i$

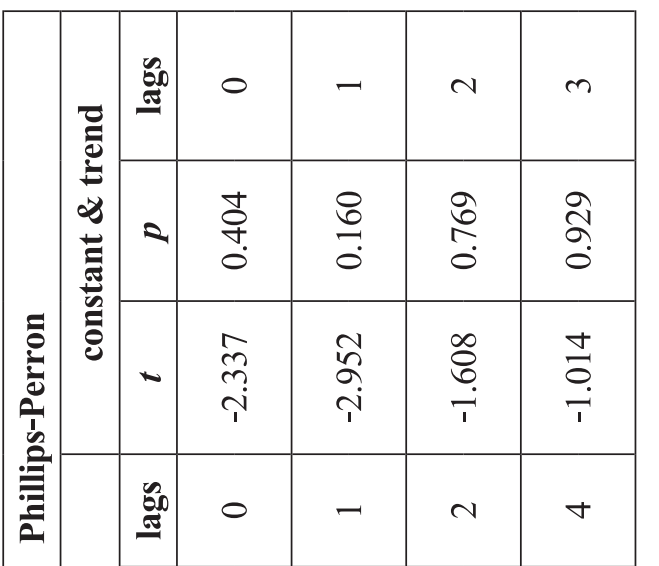

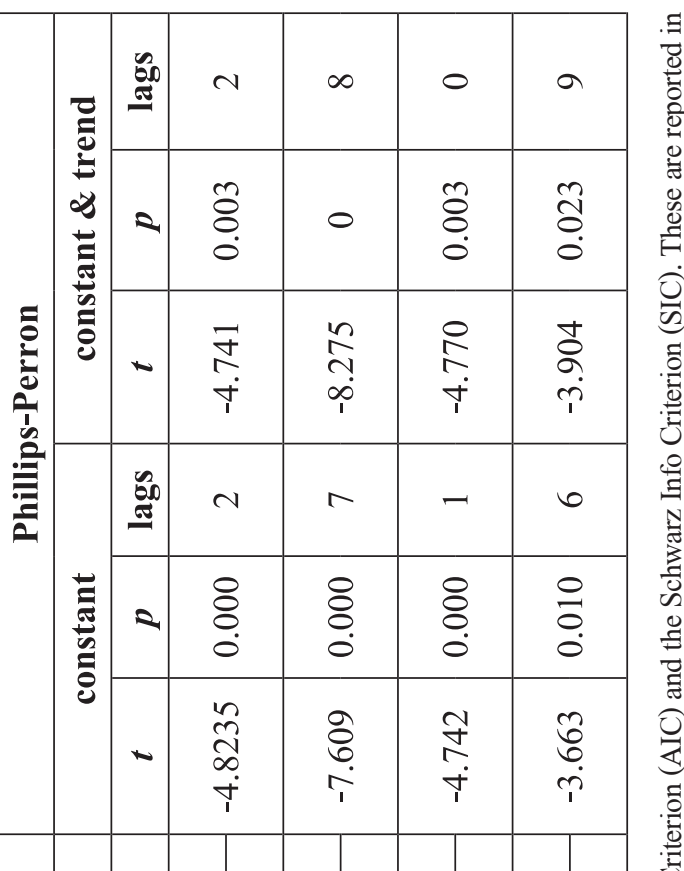

\begin{tabular}{|c|c|c|c|}
\hline 2 & $\begin{array}{l}0 \\
6 \\
0 \\
0\end{array}$ & $\begin{array}{l}\hat{\zeta} \\
0 \\
0\end{array}$ & $\begin{array}{l}\circ \\
\infty \\
\infty \\
0\end{array}$ \\
\hline$w$ & کิ) & $\begin{array}{l}\infty \\
\infty \\
\infty \\
i \\
i\end{array}$ & 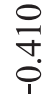 \\
\hline
\end{tabular}

כ)

$\begin{array}{cccccccc}5 & 0 & -1 & 0 & 0 & 0 & m & -1\end{array}$

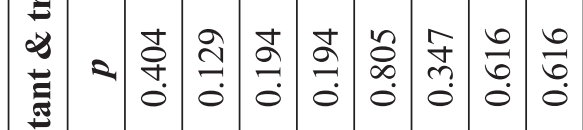

离

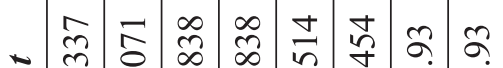

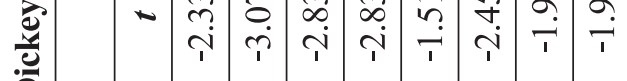

$\begin{array}{llllllllllll}E_{0}^{\infty} & 0 & 0 & 0 & 0 & 0 & m & 0 & -1\end{array}$

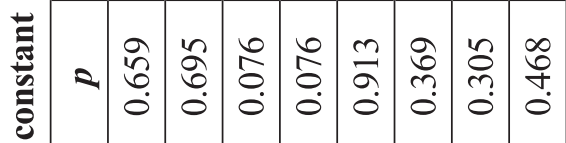

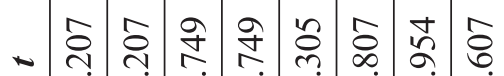

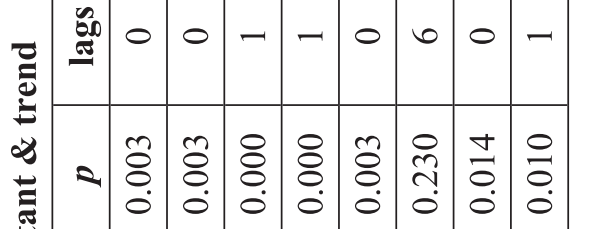

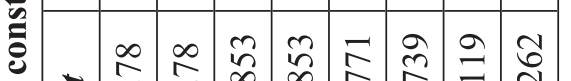

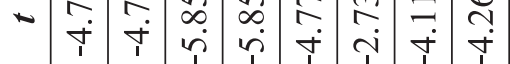

$\stackrel{Ð}{\Xi}$

窇

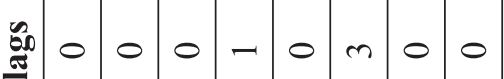

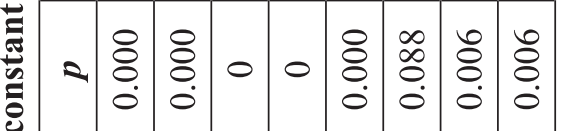

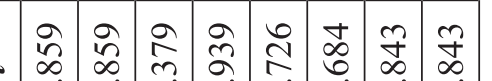

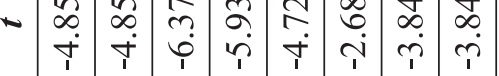

च

.

范

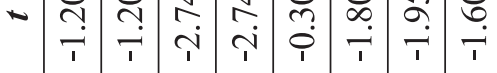

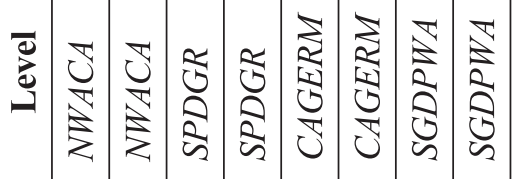

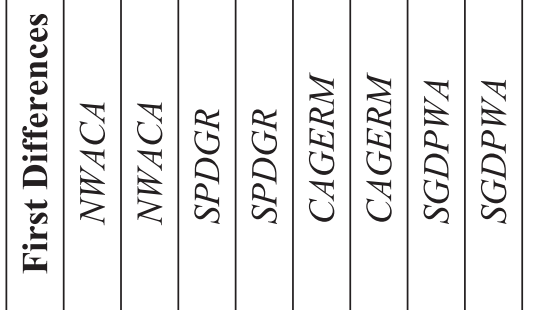

10 


\section{Appendix 2: United States balance of payment accounts}

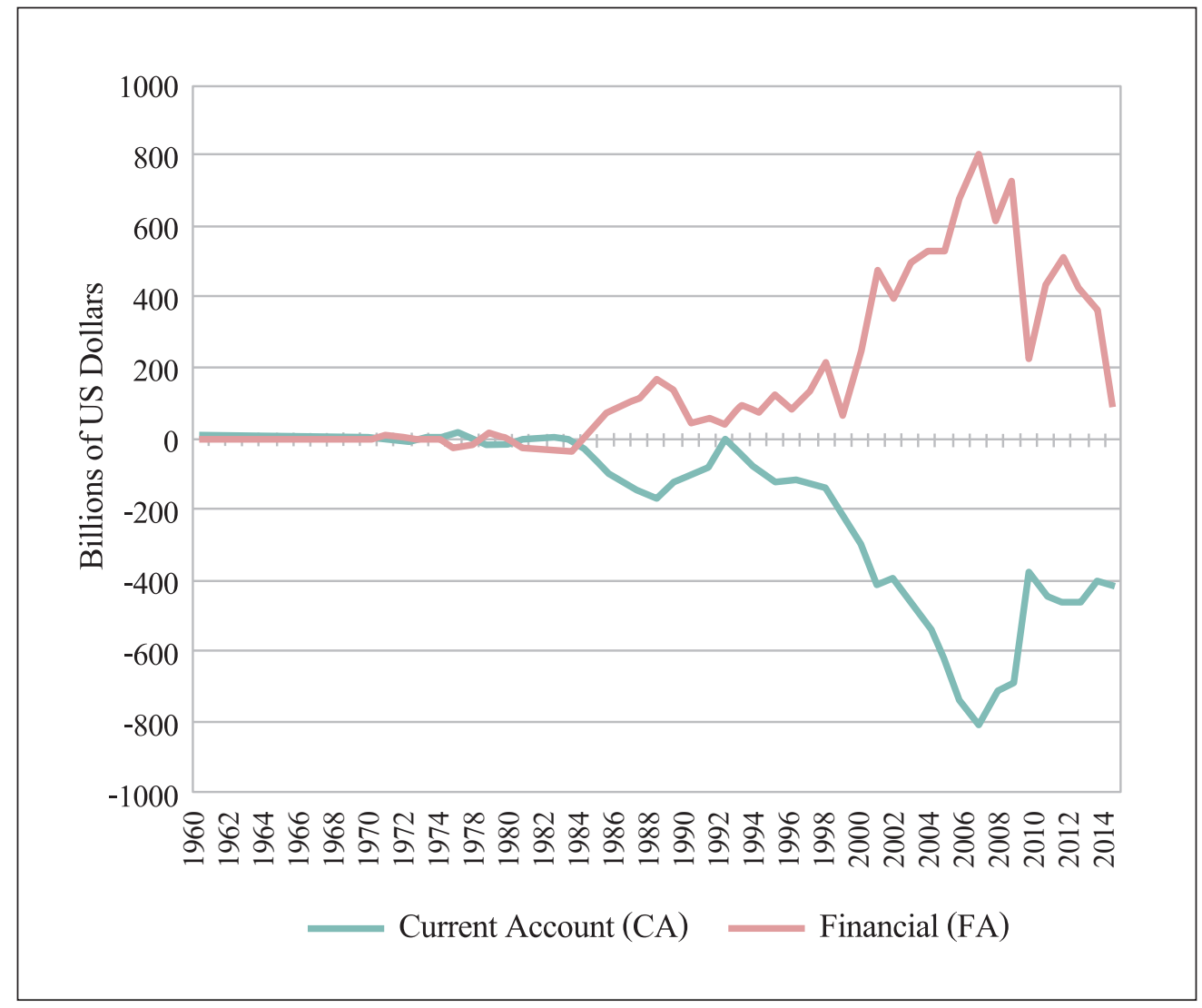

(Source) Bureau of Economic Analysis 